\title{
CARACTERES DAS SEMENTES, PLÂNTULAS E PLANTAS JOVENS DE Ormosia arborea (Vell.) Harms E Ormosia fastigiata TUL. (LEG- PAPILIONOIDEAE) ${ }^{1}$
}

\author{
Cristina Gurski², Edna Scremin Dias ${ }^{3}$ e Eduardo Arcoverde de Mattos ${ }^{4}$
}

\begin{abstract}
RESUMO - Ormosia arborea (Vell.) Harms e Ormosia fastigiata Tul. são espécies similares em muitos caracteres morfológicos, o que resulta em dificuldade na sua identificação, tanto em campo quanto em material herborizado. Neste estudo foram descritas as características morfológicas das sementes e morfoanatômicas das plântulas e plantas jovens de $O$. arborea e $O$. fastigiata, coletadas em restinga e em mata ciliar, respectivamente. Sementes e plântulas foram processadas segundo técnicas usuais. As sementes de $O$. arborea são mais pesadas e têm germinação hipógea criptocotiledonar. O caule contém tricomas tectores esparsos e grande quantidade de lenticelas e, na raiz, nodulações. A folha apresenta parênquima paliçádico de células mais curtas, com base mais larga e presença de pigmentos vacuolares, espaços intercelulares conspícuos no parênquima esponjoso, tricomas tectores restritos à nervura principal e células epidérmicas da face adaxial maiores que as da face abaxial. A germinação de $O$. fastigiata é fanerocotiledonar, e a plântula possui muitos tricomas ao longo do caule e lenticelas restritas à região basal deste. As folhas apresentam tricomas tectores em todas as nervuras, com parênquima paliçádico de células tipicamente alongadas e parênquima esponjoso com espaços intercelulares reduzidos. Tais características são consistentes para separar as plântulas e sementes dessas espécies, que têm a mesma denominação popular e contribuem com informações úteis para o meio produtivo.
\end{abstract}

Palavras-chave: Morfologia da semente, Mata ciliar e Restinga.

\section{CHARACTERS OF SEEDS, SEEDLINGS AND YOUNG PLANTS OF Ormosia arborea (Vell.) Harms AND Ormosia fastigiata Tul. (LEG-PAPILIONOIDEAE)}

\begin{abstract}
Ormosia arborea (Vell.) Harms and Ormosia fastigiata Tul. are similar species in many morphological characters, which impairs their identification both in field and herbarium specimens. This study describes morphological characteristics of seed and morpho-anatomy traits of seedlings and young plants of $\boldsymbol{O}$. arborea and $\boldsymbol{O}$. fastigiata, collected in restinga and riparian forest, respectively. Seeds and seedlings were submitted to usual anatomical techniques to make slides and analysis. Seeds of O. arborea are heavier seeds and have hypogeous cryptocotylar germination. The stem showed tector trichomes sparse and large amount of lenticels and nodules in the root. The leaf has palisade parenchyma with of shorter cells and wider at base and presence of vacuolar pigment, conspicuous intercellular spaces in the spongy parenchyma, trichomes restricted to the midrib and adaxial epidermal cells larger than abaxial face. Germination of $\boldsymbol{O}$. fastigiata is hypogeous phanerocotylar and the seedling has many trichomes along the stem and lenticels restricted to its basal region. The leaves have many trichomes on all the veins, with palisade parenchyma of elongated cells and spongy parenchyma with intercellular spaces reduced. These characteristics are consistent to separate the seeds and seedlings of the species, which have the same popular name and contribute with useful information for the productive environment.
\end{abstract}

Keywords: Seed morphology, Riparian forest and Restinga.

\footnotetext{
${ }^{1}$ Recebido em 20.06.2010 e aceito para publicação em 15.11.2011.

${ }^{2}$ Universidade Federal de Mato Grosso do Sul, Brasil. E-mail: <gurski.cristina@gmail.com>.

${ }^{3}$ Universidade Federal de Mato Grosso do Sul, Brasil. E-mail: <edna-scremin.dias@ufms.br>.

${ }^{4}$ Universidade Federal do Rio de Janeiro, Brasil. E-mail: < eamattos@biologia.ufrj.br>.
} 


\section{INTRODUÇÃO}

O gênero Ormosia Jackson pertence à subfamília Papilionoideae, tribo Sophoroe, com aproximadamente 100 espécies, amplamente distribuídas em regiões tropicais e subtropicais. Notoriamente, as espécies Ormosia arborea (Vell.) Harms e Ormosia fastigiata Tul. são similares em muitos caracteres morfológicos, dificultando sua identificação tanto em campo quanto em material herborizado (RUDD, 1965).

Conhecidas popularmente como olho-de-cabra, Ormosia arborea (Vell.) Harms e Ormosia fastigiata Tul. são arbóreas e semidecíduas. A primeira é heliófita, encontrada em Floresta Fluvial Atlântica e Latifoliada Semidecídua, distribuída nos Estados da Bahia, de Minas Gerais, Mato Grosso do Sul até Santa Catarina (LORENZI, 1998), ocorrendo em florestas e ao longo da costa em restingas (RUDD, 1965). Ormosia fastigiata Tul., também conhecida como árvore-do-tento, distribuiu-se pelo Sudeste e Centro-Oeste do Brasil, ao longo de matas ciliares, em áreas com topografia de 500-600 m (RUDD, 1965).

As sementes dessas espécies são muito semelhantes morfologicamente e, apesar da caracterização biométrica de frutos e sementes fornecer subsídio importante para a diferenciação de espécies do mesmo gênero (CRUZ et al., 2001), há dificuldade da utilização desse parâmetro para as espécies em questão, principalmente pela falta de estudos comparativos mais aprimorados. Assim, é comum as sementes dessas duas espécies serem processadas como uma única espécie, pela falta de critérios técnicos mais bem definidos.

Informações científicas sobre os parâmetros técnicos das sementes, do ciclo vegetativo, e do processo de desenvolvimento das espécies $O$. arborea e $O$. fastigiata em viveiros e, ou, em campo facilitarão a identificação de lotes de sementes destinados à comercialização, facilitando sua propagação.

Em estádios iniciais de desenvolvimento de espécies arbóreas, a utilização de caracteres morfológicos muitas vezes não é suficiente para separar espécies muito próximas. Nesse aspecto, as características anatômicas dos órgãos vegetativos podem servir como critério adicional para resolver problemas taxonômicos (METCALFE; CHALK, 1983) e diferenciar espécies em estágios iniciais de desenvolvimento. Por vezes, a análise de órgãos vegetativos e florais é insuficiente para resolver problemas taxonômicos e filogenéticos (OLIVEIRA, 2001), e a utilização de caracteres morfoanatômicos das plântulas e plantas jovens pode ser empregada tanto para identificação de plantas quanto para seu grupamento sistemático, dentro de um contexto ecológico de determinada região (OLIVEIRA, 1993).

As informações sobre o estabelecimento das plantas em ambientes naturais são essenciais para a tecnologia de produção de mudas, em trabalhos de regeneração e manejo de comunidades naturais ou implantadas, além de auxiliarem na determinação do estádio sucessional da planta em ambiente natural (DAVIDE et al., 1995; CAMARGO et al., 2000; DONADIO; DEMATTÊ, 2000; PINÃ-RODRIGUES, 2002; CUNHA; FERREIRA, 2003; RODRIGUES; TOZZI, 2007). No entanto, apesar da importância, estudos morfoanatômicos comparativos de plântulas, como auxílio no reconhecimento das fases iniciais do seu estabelecimento, são escassos e insuficientes, considerando-se a diversidade da flora brasileira.

A crescente necessidade de recomposição de ecossistemas alterados expõe lacunas no conhecimento biológico e ecológico das espécies dos diversos ecossistemas brasileiros. Nesse sentido, o fluxo de espécies e sementes entre regiões distintas do país e a frequente introdução de espécies em ambientes que naturalmente não ocorrem tornaram-se prática comum nos últimos tempos. Esses problemas, detectados em Ormosia arborea (Vell.) Harms. e Ormosia fastigiata Tul., motivaram a elaboração desta pesquisa. Além disso, os estudos morfoanatômicos que caracterizam plântulas de espécies nativas, principalmente daquelas com semelhança morfológica entre suas sementes e plântulas, contribuem para a identificação em campo e subsidiam o setor produtivo de sementes e mudas.

Neste estudo é apresentada a descrição morfológica das sementes e morfoanatômica das plântulas e plantas jovens de Ormosia arborea (Vell.) Harms. provenientes de população do Parque Nacional da Restinga de Jurubatiba, em Macaé, RJ; e de Ormosia fastigiata Tul., encontrada em mata ciliar do rio Ivinhema, em Angélica, MS. Os resultados aqui apresentados poderão subsidiar trabalhos de propagação dessas espécies para fins de reposição vegetal, fornecendo subsídios para diferenciá-las e evitando comercialização equivocada. 


\section{MATERIAL E MÉTODOS}

O estudo foi conduzido no Laboratório de Botânica do Centro de Ciências Biológicas e da Saúde da Universidade Federal do Mato Grosso do Sul. Foram utilizadas sementes de Ormosia arborea (Vell.) Harms, coletadas em indivíduos do Parque Nacional da Restinga

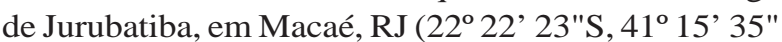
$\mathrm{W})$, cujo substrato arenoso de origem marinha é caracterizado pela baixa capacidade de retenção de água e baixo teor de matéria orgânica (CAVALIN; MATTOS, 2007). As sementes de Ormosia fastigiata Tul. foram obtidas em população de um trecho de mata ciliar do rio Ivinhema, em Porto Angélica, Município

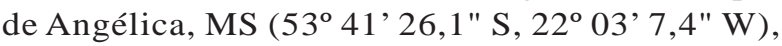
distribuída próximo à margem do rio, em áreas sujeitas à inundação.

Foi avaliada a morfometria das sementes por meio da mensuração do comprimento, da espessura e do diâmetro, bem como anotados a forma, coloração, textura, formato do hilo, forma e coloração do embrião, cotilédones e eixo hipocótilo-radícula, utilizando estereomicroscópio Leica MZ 125. As medidas, efetuadas com o auxílio de régua milimétrica e paquímetro digital, foram obtidas em 50 sementes, sendo a massa calculada a partir de 150 sementes retiradas aleatoriamente de amostra mista, pesadas em balança analítica de precisão. Os dados foram submetidos aos testes de normalidade (Shapiro-Wilk) e homogeneidade das variâncias (teste F), sendo realizados a análise de variância (ANOVA) e o pós-teste de Tukey (ZAR, 1996), com o auxílio do software Systat Version 10.

Para a germinação, 50 sementes de ambas as espécies foram acondicionadas em placas de Petri de $9 \mathrm{~cm}$ de diâmetro, contendo vermiculita em câmara germinadora BOD na temperatura de $30^{\circ} \mathrm{C} \pm 1^{\circ} \mathrm{C}$, sob luz contínua. O material obtido dos experimentos de germinação foi destinado ao estudo do desenvolvimento da plântula e da planta jovem e para a produção de mudas em viveiro. No viveiro do Laboratório de Botânica, as plântulas foram replantadas em sacos de polietileno pretos com dimensões de $16 \mathrm{x}$ $25 \mathrm{~cm}$, com capacidade para cerca de 2,0 kg de areia de textura média como substrato. Para a descrição morfoanatômica, as plântulas foram amostradas em duas fases, de 1 a 30 dias após a germinação, e as plantas jovens aos 90 dias, utilizando-se cinco plântulas e plantas jovens, sendo uma selecionada para ilustração, com o auxílio de câmara clara acoplada a um estereomicroscópio.
A primeira fase, a da germinação, teve início com a emissão da radícula até a formação do primeiro par de eofilo; a segunda fase - de planta jovem ou tirodendro -, com a formação da raiz, caule jovem, apresentou os primeiros nomofilos. Os termos empregados estão de acordo com Ferri (1988), Barroso (1991), Barroso (1999) e Vidal e Vidal (1995), e a classificação dos tipos morfológicos das plântulas foi baseada na classificação elaborada por Míquel (1987) e Souza (2003 e 2009).

As descrições anatômicas das plântulas foram realizadas em material fresco e fixado em FAA 50\% (JOHANSEN, 1940), por meio de cortes transversais, efetuados à mão livre, com o auxílio de lâmina de aço. As secções feitas no primeiro e segundo entrenós do caule, na região do colo, no ápice e região basal da raiz primária e na região mediana dos nomofilos; e os cortes paradérmicos na lâmina foliar foram clareados em solução de hipoclorito de sódio $20 \%$, corados com safranina aquosa $1 \%$ e azul de astra em solução aquosa $1 \%$ (BUKATSH, 1972). As lâminas semipermanentes foram montadas em glicerina 50\% (JOHANSEN, 1940). A presença de amido foi avaliada com cloreto de zinco iodado (JENSEN, 1962) e de cristais de carbonato ou oxalato de cálcio foi testada com ácido clorídrico, seguindo-se técnicas compiladas por Kraus e Arduin (1997). Toda a documentação foi realizada em fotomicroscópio Leica MC 80 e estereomicroscópio Leica MZ 125, acoplados ao sistema de captura de imagens.

\section{RESULTADOS}

\subsection{Morfologia da semente}

O formato da semente variou de elíptica a oblonga em $O$. fastigiata (Figura 1A) e de ovada a arredondada em $O$. arborea (Figura 1B), ambas com tegumento de textura lisa e testa bicolor, vermelha e preta. O comprimento médio da semente de $O$. fastigiata foi de $1,18( \pm 0,27) \mathrm{cm}$, e o diâmetro e a espessura médios foram de 0,89 $( \pm 0,14) \mathrm{cm}$ e $0,71( \pm 0,11) \mathrm{cm}$, respectivamente. Em O. arborea, o comprimento médio foi de $1,15( \pm 0,17) \mathrm{cm}$, com diâmetro e espessura médios de $0,92( \pm 0,19) \mathrm{cm}$ e $0,75( \pm 0,12) \mathrm{cm}$, respectivamente. O. arborea apresentou média da massa das sementes superior à obtida em O. fastigiata $(\mathrm{p}<0,01, \mathrm{~F}=15,750)$. Obtiveram-se 61,9 g em lote de 100 sementes de $O$. fastigiata (massa individual média de 0,628 g) e 69,67 g em lote de 100 sementes de O. arborea (massa individual média de 0,685 g).

Revista Árvore, Viçosa-MG, v.36, n.1, p.37-48, 2012 


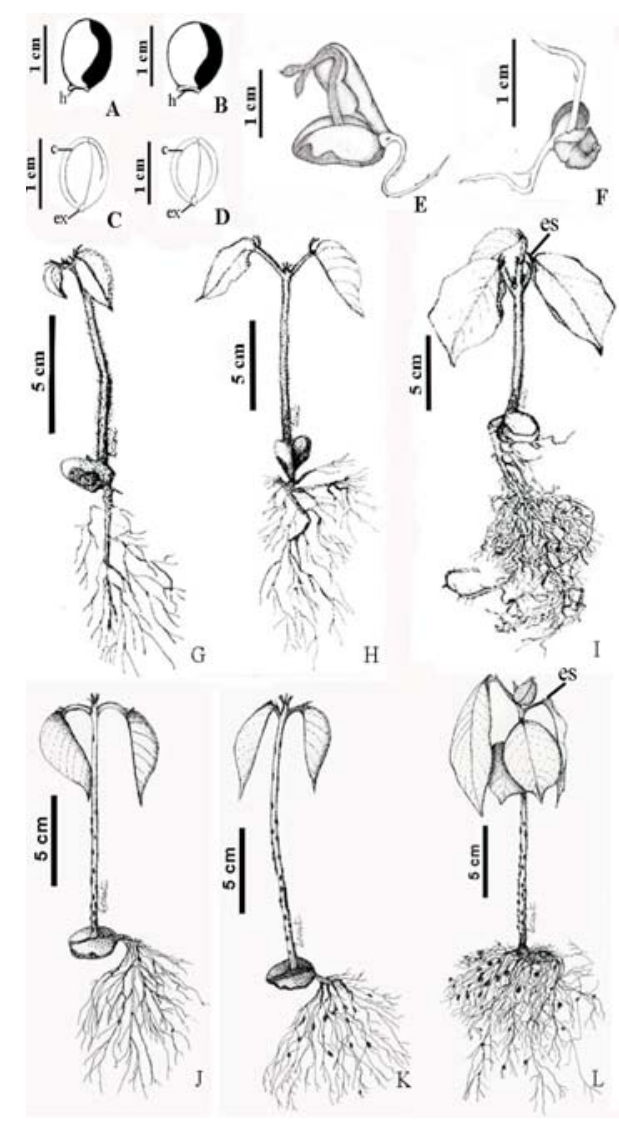

Figura 1 - Caracterização morfológica da semente, plântulas e plantas jovens de Ormosia fastigiata Tul. e Ormosia arborea (Vell.) Harms. A: Semente de O. fastigiata. B: Semente de O. arborea. C: Embrião de $O$. fastigiata. D: Embrião de O. arborea. E: Estádio de desenvolvimento inicial da plântula de $O$. arborea. F: Estádio de desenvolvimento inicial da plântula de $O$. fastigiata. G-I: Planta jovem de $O$. fastigiata aos 30 dias $(\mathrm{G})$, aos 60 dias $(\mathrm{H})$ e aos 90 dias de desenvolvimento (I). J-L: Planta jovem de $O$. arborea aos 30 dias (J), aos 60 dias (K) e aos 90 dias de desenvolvimento (L); c: cotilédone, es: estipela, ex: eixo-embrionário e h: hilo.

Figure 1 - Morphological characterization of seeds, seedlings and young plants of Ormosia fastigiata Tul. and Ormosia arborea (Vell.) Harms. A - Seed of O. fastigiata. B Seed of O. arborea. C - Embryo of O. fastigiata. D - Embryo of O. arborea. E early seedling development stage of O. arborea. F. early seedling development stage of $\boldsymbol{O}$. fastigiata. $G$ I. Young plant of $\boldsymbol{O}$. fastigiata at 30 days $(G)$, 60 days $(H)$ and 90 days of development (I). $J$ $L$. Young plant of $O$. arborea at 30 days $(J), 60$ days $(K)$ and 90 days of development $(L) ; c$ : cotyledon, es: stipel, ex-embryonic axis and $h$ - hilum.
Nessas espécies, o hilo é semicircundante, elíptico, heterócromo (cor esbranquiçada quando o funículo é removido), próximo à base da semente e fenda hilar, pouco perceptível. O embrião de cor creme é invaginado, globoso, sendo ligeiramente alongado em $O$. fastigiata (Figura 1C), com cotilédones crassos, plano-convexos, dispostos perpendicularmente ao eixo hipocótilo-radícula, que é reto e curto, com tamanho diminuto em relação ao restante da semente (Figura 1CD).

\subsection{Desenvolvimento da plântula e da planta jovem}

A germinação de ambas as espécies é hipógea. O. fastigiata apresentou germinação hipógea fanerocotiledonar, com cotilédones expostos ao nível do solo, parcialmente inseridos no tegumento, adquirindo coloração verde. $O$. arborea apresentou germinação do tipo hipógea criptocotiledonar, com cotilédones inseridos no tegumento da semente, permanecendo ao nível do solo.

A emissão da raiz primária de cor amarelo-creme e coifa de coloração branca ocorreu cinco dias após a embebição da semente em $O$. arborea e sete dias em $O$. fastigiata, com a ruptura do tegumento na base da semente, abaixo da região hilar nas duas espécies (Figura 1E). O hipocótilo é curto, cilíndrico e de coloração esbranquiçada. O epicótilo tornou-se visível a partir do décimo dia de germinação em $O$. arborea e a partir do $12^{\circ}$ dia em $O$. fastigiata, crescendo encurvado até o momento da sua saída do tegumento (Figura 1EF). Posteriormente, tornou-se alongado, cilíndrico, de coloração verde-clara, com muitos tricomas simples, inicialmente esbranquiçados, em ambas as espécies.

$\mathrm{Na}$ sequência ocorreu a emissão de raízes secundárias finas, tenras e cilíndricas, da mesma cor da raiz primária, adquirindo posteriormente cor branca amarelada, nas duas espécies. A plúmula de cor verdeclara no ápice do epicótilo dispõe-se entre os dois eofilos (Figura 1C). Estes apresentam coloração verdeclara, densa pilosidade esbranquiçada nas nervuras da face abaxial em $O$. fastigiata, visível somente sob lupa; em O. arborea, a pilosidade esteve restrita à nervura principal. As plântulas desenvolvem-se rapidamente e, com 20 dias, os eofilos são amplos. Ambas as espécies possuem eofilos unifoliados de filotaxia oposta, obovados ou ovados, pinados, com folhas e margens inteiras, ápice acuminado, base arredondada e duas estipelas lanceoladas (Figura 1G-I). A plúmula de cor verde-clara bem desenvolvida no 
ápice do epicótilo é rodeada por quatro estípulas lanceoladas. O epicótilo de $O$. fastigiata apresentou muitos tricomas (Figura 1H) de coloração marrom.

Após 30 dias da protrusão da radícula, o desenvolvimento da plântula é rápido, com mudança de filotaxia para alterna (Figura 1G-I). Os nomofilos possuem no início do desenvolvimento coloração avermelhada e bordos amarelos, tornando-se verdeclaros posteriormente. A venação é broquidódroma, mais evidente na face abaxial. Nomofilos de $O$. fastigiata possuem formato ovado a oblongo, com ápice agudo, base arredondada a obtusa e bordo inteiro, pecíolo curto, piloso e verde-claro, além de duas estipelas conspícuas na base de cada folha (Figura 1I).

A planta jovem de $O$. fastigiata, após 90 dias de desenvolvimento, apresenta raiz primária axial cilíndrica, de cor branca amarelada, com base engrossada de consistência lenhosa, ligeiramente sinuosa e afinando em direção ao ápice (Figura 1G). As raízes secundárias finas, de coloração semelhante à da raiz principal, possuem tamanho variável, são sinuosas, tenras, distribuídas ao longo da raiz primária e com raízes terciárias bem desenvolvidas.

O caule jovem de ambas as espécies é reto, verdeescuro, cilíndrico, com base engrossada, afinando em direção ao ápice. A região basal do caule tem textura sublenhosa e herbácea acima do primeiro nó. Em $O$. fastigiata, o caule é fulvitomentoso (Figura 1I), com muitos tricomas marrons, e a gema apical de cor verdeclara está inserida entre os nomofilos, no ápice do caule.

A diferença mais conspícua das plântulas de $O$. arborea diz respeito ao epicótilo, que apresentou inúmeras lenticelas distribuídas ao longo do caule, já visíveis aos 30 dias de desenvolvimento, e tricomas tectores em menor quantidade e com distribuição irregular (Figura 1J).

Acompanhando o desenvolvimento das plântulas das duas espécies em viveiro, ficou evidenciado que O. arborea (Figuras $1 \mathrm{~J}-\mathrm{L}$ ), com o mesmo tempo de desenvolvimento e nas mesmas condições que $O$. fastigiata, apresentou plantas visivelmente maiores. A raiz primária de ambas as espécies possui colo espessado de coloração distinta do caule jovem e da raiz primária. Nessa região, em ambas as espécies é visível a periderme com lenticelas, mais evidentes em O. arborea (Figura $1 \mathrm{H}-\mathrm{J}$ ), sendo facilmente visualizadas sob lupa as estrias e fendas, que favorecem a descamação desse tecido.
Os nomofilos de O. arborea têm forma variando de elíptica a ovada, larga, com ápice acuminado, base arredondada e bordo inteiro e pecíolo curto (Figura 1L), piloso e verde-claro.

No sistema radicial de $O$. arborea ocorrem numerosos nódulos, a partir do terceiro mês de desenvolvimento da plântula (Figura $1 \mathrm{~J}-\mathrm{L}$ ), não sendo observadas nodulações em raízes de $O$. fastigiata (Figuras 1G-I).

\subsection{Anatomia da planta jovem}

O caule da planta jovem ao nível do primeiro entrenó, em ambas as espécies, apresenta epiderme de células retangulares recobertas por cutícula fina, flanges cuticulares e tricomas simples bicelulares, mais abundantes em $O$. fastigiata (Figura 2A). O córtex de $O$. fastigiata possui cerca de oito camadas celulares com as três camadas subjacentes à epiderme de paredes ligeiramente espessas, com aspecto colenquimatoso (Figura 2AB). Cristais de oxalato de cálcio foram encontrados em células corticais e em células da endoderme (Figuras 2BC), também presentes no córtex de O. arborea (Figuras 2DE). Este é constituído por cerca de oito camadas celulares, com duas a três camadas de colênquima angular abaixo da epiderme, seguidas por parênquima (Figura 2F). Ambas as espécies possuem endoderme com amido, limitando o cilindro vascular, seguida pelas fibras perivasculares do floema primário (Figura 2B-D).

O câmbio inicialmente fascicular com disposição lobada, devido ao fato de acompanhar o formato das unidades vasculares, é bem ativo ao nível do primeiro entrenó nas espécies, com o xilema secundário bem desenvolvido nessa região (Figura 2B-D). Nessa região, o cilindro central tem contorno ligeiramente lobado, porém contínuo, refletindo o arranjo do sistema vascular primário. Dois traços foliares conspícuos podem ser observados na região do nó (Figura 2A), devido à filotaxia alterna dos nomofilos. A medula é composta por células parenquimáticas com grãos de amido e compostos fenólicos nas duas espécies (Figura 2AFG).

Na região basal do caule, foram observadas lenticelas em $O$. fastigiata e $O$. arborea, mais desenvolvidas e em maior quantidade nesta última espécie (Figura 2H-I). Sua origem ocorreu a partir do felogênio, formado a partir de camadas subepidérmicas, constituída por uma a três camadas de feloderme da lenticela e, externamente, seis camadas de células

Revista Árvore, Viçosa-MG, v.36, n.1, p.37-48, 2012 


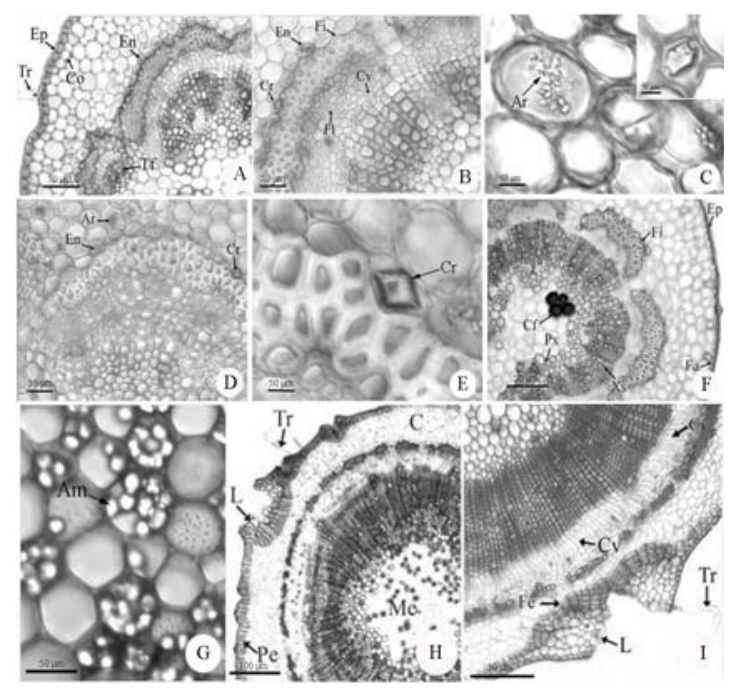

Figura 2 - Secções transversais do primeiro e segundo nós (Figura A-F) e da região basal do caule (Figura G-I) de Ormosia arborea (Vell.) Harms e de Ormosia fastigiata Tul. em plantas jovens. A-B: Córtex e detalhe do cilindro vascular de $O$. fastigiata. C: Células do córtex de $O$. fastigiata com areias cristalíferas e detalhe de uma célula com cristal de oxalato de cálcio. D: Sistema vascular do caule de O. arborea. E: Detalhe de uma célula da endoderme de O. arborea com cristal de oxalato de cálcio. F: Aspecto geral do caule de O. arborea. G: Células da medula de $O$. arborea com grãos de amido. H: Região basal do caule de O. arborea. F: Região basal do caule de $O$. fastigiata; Am: grãos de amido, Ar: areias cristalíferas, Cf: compostos fenólicos, Co: colênquima, Cr: cristais, Cv: câmbio vascular, En: endoderme, Ep: epiderme, Fa: flanges, Fe: felogênio, Fi: fibras, Fl: floema, L: lenticela, Me: medula, Pe: periderme, Px: protoxilema, Tf: traço foliar, Tr: tricoma e Xs: xilema secundário.

Figure 2-Cross sections of the first and second nodes (Figures A-F) and the basal stem (Figuras G-I) of Ormosia arborea (Vell.) Harms and Ormosia fastigiata Tul. in Young plants. A-B. Cortex and detail of the vascular cylinder of $\boldsymbol{O}$. fastigiata. C. Cortical cells of $\boldsymbol{O}$. fastigiata with crystal sands and a detail of cell with calcium oxalate crystal. D. Vascular system of O. arborea. E. Detail of an endodermal cell of $\boldsymbol{O}$. arborea with calcium oxalate crystal. F. General appearance of the stem of $\boldsymbol{O}$. arborea. G. Pith cells of $O$. arborea with starch grains. $H$. Basal stem of O. arborea. .I. Basal stem of O. fastigiata; Am: starch grains, Ar: crystal sands, Cf: phenolic compounds, Co: collenchyma, Cr: crystals, Cv: vascular cambium, En: endoderm, Ep: epidermis, Fa: flanges, $\mathrm{Fe}$ : phellogen, Fi: fibers, Fl: phloem, L: lenticel, $\mathrm{Me}$ : pith, $\mathrm{Pe}$ : periderm, Px: protoxylem, Tf: leaftrace, Tr: trichome and $X$ s: secondary xylem. suberizadas (Figura 2H). A Figura 2I ilustra as lenticelas de $O$. fastigiata formadas antes do estabelecimento do restante da periderme, isso porque o felogênio da lenticela atua diferentemente do felogênio da periderme. No caso de O. arborea e O. fastigiata, as primeiras células formadas são mais ou menos uniformes e compactadas, características do felogênio e de suas derivadas imediatas, tendendo a se separar mais tarde e produzindo um tecido frouxo pouco desenvolvido externamente, sem camadas de oclusão.

Secções transversais da região apical da raiz de ambas as espécies indicam a presença de epiderme unisseriada, revestida por cutícula delgada e córtex de aproximadamente oito camadas parenquimáticas, com espaços intercelulares conspícuos limitados pela endoderme, de células menores e distintas das demais (Figura 3A), sem a presença de estrias de Caspary evidentes. Internamente à endoderme, uma camada celular - o periciclo - limita o sistema vascular, que apresenta três polos de protoxilema - raiz triarca nas duas espécies, com floema intercalado com o protoxilema, e no centro do cilindro vascular verifica-se metaxilema em formação (Figura 3A). Na base da raiz de O. arborea, início da região de transição ou colo, o crescimento secundário já está estabelecido e evidenciado pela instalação do câmbio e do felogênio (Figura 3B). Os tecidos externos ao cilindro central já estão sendo (Figura 3B) ou já foram totalmente eliminados (Figura 3C), devido a divisões periclinais do periciclo para formar o felogênio. Neste estudo, apesar de não quantificado, foi evidente o menor diâmetro das raízes de $O$. fastigiata em comparação com $O$. arborea, visualizadas nas secções transversais, além da presença de numerosos nódulos (Figura 3D). Os nomofilos de plantas jovens de O. arborea e $O$. fastigiata têm epiderme da face superior com células de paredes anticlinais sinuosas (Figura 4A) e recobertas por cutícula delgada. A epiderme da face inferior assemelha-se à da face superior, com tricomas tectores bicelulares de célula basal curta e apical alongada, em todas as nervuras em O. fastigiata (Figura 4B) e somente na nervura principal em O. arborea (Figura 4C). Estômatos paracíticos estão amplamente distribuídos somente na face abaxial em ambas as espécies (Figura 4A). O feixe vascular da nervura mediana apresenta xilema e floema distribuídos em disposição de meia lua, sendo limitado por uma faixa de fibras perivasculares de esclerênquima circundada por várias camadas de parênquima regular e duas de colênquima subepidérmico na face abaxial (Figura 4D). 

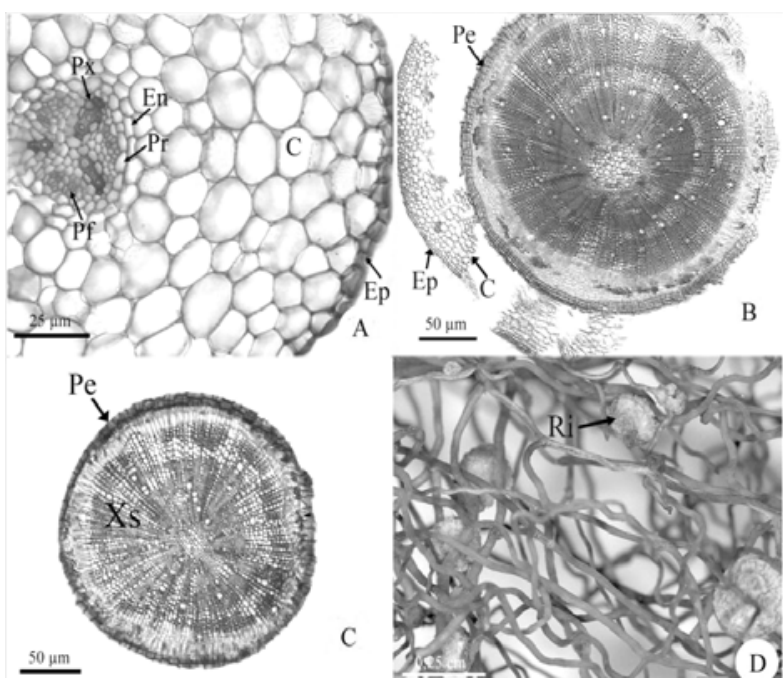

C

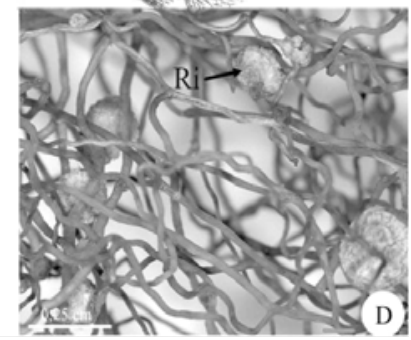

Figura 3 - Secção transversal da raiz primária de plantas jovens de Ormosia arborea (Vell.) Harms e de Ormosia fastigiata Tul. A: Ápice da raiz primária de O. arborea. B: região basal (zona de transição) da raiz de $O$. arborea. C: Região basal (zona de transição) da raiz de $O$. fastigiata. D: Nodulações (setas) evidenciadas nas raízes de $O$. arborea. C: córtex; En: endoderme, Ep: epiderme, Pe: periderme, Pr: periciclo, Pf: protofloema, Px: protoxilema, Ri: rizóbio e Xs: xilema secundário.

Figure 3-Cross sections of primary roots of young plants of Ormosia arborea (Vell.) Harms and of Ormosia fastigiata Tul. A. Apex of the primary root of $\boldsymbol{O}$. arborea. B. Basal root (transition zone) of $\boldsymbol{O}$. arborea. C. Basal root (transition zone) of $\boldsymbol{O}$. fastigiata. D. Nodules (arrows) detected in the roots of O. arborea; C: cortex, En: endodermis, Ep: epidermis, $P e$ : periderm, Pr: pericycle, Pf: protophloem, $P x$ : protoxylem, Ri: rhizobia and Xs: secondary xylem.

O mesofilo é dorsiventral, com uma camada de células em paliçada e três a quatro camadas de parênquima esponjoso (Figura 4EF). O parênquima paliçádico das folhas de $O$. fastigiata é constituído por células alongadas, intimamente unidas, e o parênquima esponjoso apresenta espaços intercelulares reduzidos (Figura 4E), quando comparado com numerosos e amplos espaços intercelulares de $O$. arborea. O parênquima paliçádico desta espécie é constituído por células com presença de pigmentos vacuolares, mais curtas, com uma base mais larga, de distribuição irregular, formando uma camada mais delgada quando comparada com $O$. fastigiata. Além disso, em O. arborea é possível visualizar

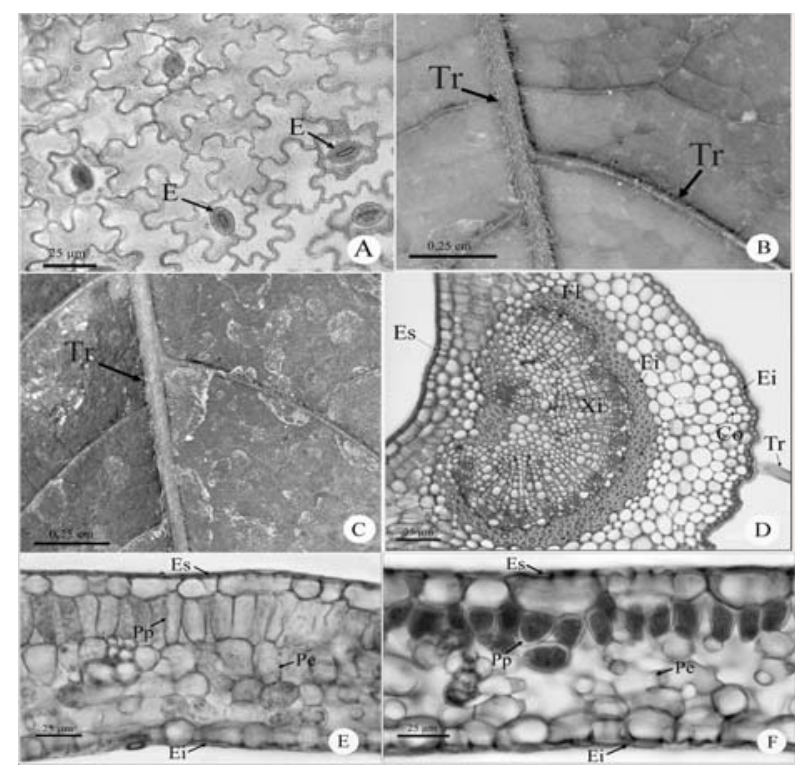

Figura 4 - Nomofilos de Ormosia arborea (Vell.) Harms (Figura ACF) e de Ormosia fastigiata Tul (Figura BDE). A: Secção paradérmica da epiderme de $O$. arborea. B: Face abaxial da lâmina foliar de $O$. fastigiata. C: Face abaxial da lâmina foliar de $O$. arborea. D: Nervura mediana de $O$. fastigiata. E: Mesofilo de $O$. fastigiata. F: Mesofilo de $O$. arborea; Co: colênquima, E: estômato, Ei: epiderme da face inferior, Es: epiderme da face superior, Fi: fibras, Fl: floema, Pe: parênquima esponjoso, Pp: parênquima paliçádico e Tr: tricoma.

Figure 4 - Nomophylls of Ormosia arborea (Vell.) Harms. (Figures $A, C$ and $F$ ) and of Ormosia fastigiata Tul. (Figures B, D and E). A. Paradermic section of epidermis of O. arborea. B. Abaxial face of O. fastigiata. C. Abaxial face of O. arborea. D. Midrib of O. fastigiata. E. Mesophill of O. fastigiata. F. Mesophill of O. arborea. Co: collenchyma, Ei: lower epidermis, Es: upper epidermis, Fi: fiber, Fl: phloem, Pe: spongy parenchyma, Pp: palisade parenchyma, Tr: trichome and S: stomata.

a diferença no tamanho das células epidérmicas da face adaxial, que são maiores em relação às da face abaxial (Figura 4F).

\section{DISCUSSÃO}

As sementes idênticas das duas espécies, classificadas como mimética por Barroso (1999) e Van der Pijl (1982), cuja testa dura e a coloração chamativa, à semelhança das comestíveis (VAN DER PIJL, 1982), “enganam” os pássaros que as comem, defecando-as intactas. Comumente essa característica é observada

Revista Árvore, Viçosa-MG, v.36, n.1, p.37-48, 2012 
em campo segundo Ressel et al. (2004), que por meio da observação direta indicaram a dispersão zoocórica de $O$. fastigiata sem maiores detalhes sobre os agentes dispersores.

A fenda hilar típica das Papilionoideae (BARROSO, 1991) não é evidente nas duas espécies, ocorrendo em outras espécies desta subfamília, como descrito para as sementes de Dipteryx alata Vogel (FERREIRA et al., 1998) e Amburana cearensis (Arr. Cam.) A.C. Smith (CUNHA; FERREIRA, 2003), ambas com fenda hilar conspícua.

Uma diferença marcante entre as espécies ocorreu na massa das sementes, superior em O. arborea, provavelmente devido ao seu hábitat mais restritivo, uma vez que espécies de ambientes com menor disponibilidade de recursos tendem a apresentar sementes maiores (HUANTE et al., 1995), o que significa mais recursos para o desenvolvimento nos estágios iniciais da plântula.

A germinação hipógea observada nas espécies, de acordo com Moreira e Moreira (1996), é condição derivada e predominou na maioria das Papilionoideae, grupo de leguminosas mais recentes, por eles estudadas. A germinação hipógea fanerocotiledonar de $O$. fastigiata, conforme classificação de Míquel (1987), com os cotilédones permanecendo parcialmente expostos e com coloração verde, indica função de fotossíntese, além de armazenamento. Esse tipo de germinação já havia sido descrito para essa espécie por Ressel et al. (2004) e para Ormosia discolor Spr. ex Bth. e Ormosia macrocalyx Ducke por Moreira e Moreira (1996). O tipo de germinação criptocotiledonar observada em O. arborea pode ser caráter relacionado à sua distribuição, uma vez que é comumente encontrado em formações vegetais sujeitas a condições climáticas adversas, em que o tegumento atuaria como barreira, protegendo os cotilédones (RESSEL et al., 2004). Para Vogel (1980), as plantas com esse tipo de germinação seriam mais resistentes, por possuírem suas reservas protegidas pelo tegumento da semente. Esse tipo de germinação foi descrito por Rodrigues e Tozzi (2007) em O. arborea e em Ormosia excelsa Bth por Moreira e Moreira (1996).

O desenvolvimento das plântulas corrobora em muitos aspectos o descrito para outras espécies da subfamília (MOREIRA; MOREIRA, 1996; FERREIRA et al., 1998; CUNHA; FERREIRA, 2003; RODRIGUES;
TOZZI, 2007). Os eofilos inicialmente unifoliados, com filotaxia oposta, de acordo com Rodrigues e Tozzi (2007) ocorre em quase todas as espécies neotropicais de Ormosia. A fase de tirodendro, caracterizada pela presença dos primeiros nomofilos (SOUZA, 2003; 2009) que surgem na sequência dos eofilos e são semelhantes às folhas das plantas adultas (BURGER, 1972; VOGEL, 1980), com mudança de filotaxia, que passa a ser alterna, ocorreu a partir de 30 dias nas plântulas das duas espécies avaliadas.

As duas estipelas que não persistem nos indivíduos adultos, observadas na base de cada folha das plantas jovens dessas espécies, corroboram o descrito por Rudd (1965) para esse gênero. O mesmo foi observado por Rodrigues e Tozzi (2007) em espécies de Ormosia estudadas, destacando ser as estípulas geralmente de difícil observação em material adulto depositado em herbários. Em plantas adultas de outras espécies do gênero, a exemplo de Ormosia vicosana Rudd, as estípulas são caducas e as estipelas, ausentes (RODRIGUES; GARCIA, 2007).

Lenticelas, presentes nas duas espécies, não foram encontradas em O. arborea no trabalho de Rodrigues e Tozzi (2007), que relacionaram a presença dessas estruturas em outras espécies da subfamília (Cyclolobium brasiliense Benth., Diplotropis martiusii Benth. e Poecilanthe parviflora Benth.). Esses autores também não citaram a presença de nódulos radiculares em $O$. arborea, como observado nos resultados deste estudo. No entanto, Barbieri et al. (1998), estudando a nodulação em leguminosas florestais, constataram a presença de nódulos em O. arborea, corroborando os resultados desta pesquisa. Simbioses com bactérias fixadoras de nitrogênio podem ocorrer em espécies do gênero Ormosia, assim como acontece em muitas espécies de leguminosas (RUDD, 1965). Considerando que os substratos utilizados no experimento deste estudo foram os mesmos, pode-se sugerir que sementes de O. arborea possam ter sido inoculadas em seu ambiente natural. A presença de nodulações em plantas de restingas pode estar relacionada com a menor disponibilidade de nutrientes no solo daquele ambiente. Contudo, a nodulação pode ser tardia em algumas espécies, bem como estar relacionada às características do substrato (SILVA et al., 1988), sendo que $O$. fastigiata possui capacidade de estabelecer associação com bactérias fixadoras de nitrogênio (SPRENT, 2001). De qualquer modo, a capacidade de nodulação é característica 
importante dos pontos de vista econômico e ecológico, pois, pode viabilizar reflorestamentos, minimizando a utilização de insumos nitrogenados (BARBIERI et al., 1998). Chaves et al. (2006), por exemplo, estudando o crescimento de mudas de Anadenanthera macrocarpa (Benth) Brenan, destacaram a importância da inoculação das sementes, concluindo que as mudas com maior probabilidade de sobrevivência no campo são, provavelmente, aquelas cujas sementes foram inoculadas com rizóbio.

A anatomia do caule e da raiz das espécies avaliadas revelou organização semelhante e reflete características comuns a muitas espécies (ESAU, 1977; METCALFE; CHALK, 1983; FAHN, 1990). Apesar de não quantificado, o maior espessamento desses órgãos em O. arborea, facilmente evidenciado nas secções transversais, foi característica diferencial entre as espécies e pode estar relacionado a maior quantidade de recursos alocados nas sementes da espécie, refletindo a maior massa obtida de ambas, já que sementes maiores tendem a produzir plantas com maior biomassa, capacitando-as a se estabelecer em ambientes com baixa disponibilidade de recursos (FENNER, 1983), a exemplo das restingas.

A anatomia foliar, indicando para ambas as espécies células epidérmicas com contorno sinuoso, é caráter associado a plantas de sombra ou de ambientes úmidos (WILKINSON, 1979), justificando essa característica em $O$. fastigiata. Isso porque, em folhas expostas à sombra, as paredes celulares permanecem delicadas e plásticas por mais tempo, o que favorece a formação de ondulações (WATSON, 1942). Contudo, possivelmente esse seja um caráter altamente conservado dentro do gênero, uma vez que $O$. arborea está exposta à alta intensidade luminosa em seu hábitat e também apresentava essa característica. O desenvolvimento de estratégias adaptativas específicas, a exemplo do maior tamanho das células epidérmicas na face adaxial de $O$. arborea, e a ocorrência de pigmentos vacuolares podem estar fortemente relacionados à fisiologia das plantas (GARNIER et al., 2001) ou, ainda, refletir proteção das folhas ao excesso de luz e radiação UV (SIMS; GAMON, 2002) e contra a predação (CARVALHO et al., 2007). Esses resultados evidenciam que as características foliares podem ser adaptativas para essas espécies, refletindo propriedades foliares importantes para o limite de sua distribuição.

A característica da presença de tricomas apenas na face abaxial de ambas as espécies, em todas as nervuras de $O$. fastigiata e somente na nervura principal de O. arborea, tem valor taxonômico, pois foi consistente para diferenciar plântulas e plantas jovens das duas espécies avaliadas. A presença de tricomas tectores densamente distribuídos em folhas e caules pode atuar como barreira mecânica, evitando, por exemplo, a perda excessiva de água (WERKER, 2000), o que explicou a maior densidade desse indumento em caules e folhas de O. fastigiata, em comparação com O. arborea.

Os estômatos paracíticos também estiveram restritos à face abaxial, sendo um dos caracteres mais comuns em plantas terrestres, por diminuírem a perda de água por evapotranspiração através dos estômatos, já que a face abaxial está menos exposta a altas temperaturas (LLERAS, 1977).

Mesofilo formado por poucas camadas celulares observado nas duas espécies, de acordo com Esau (1976), são comuns em folhas finas, cujo mesofilo é constituído por células curtas e arredondadas, podendo ocorrer apenas uma camada de parênquima paliçádico e, assim, corroborar os dados das duas espécies avaliadas. Entretanto, folhas de O. fastigiata apresentam parênquima paliçádico de células mais alongadas e justapostas e com menos espaços intercelulares no mesofilo esponjoso. De acordo com Fahn (1990), essas características são comuns em plantas de ambientes mais secos, pois células mais unidas minimizam a exposição das superfícies, evitando a perda excessiva de água. Já $O$. arborea possui células periformes, com numerosos espaços intercelulares, sendo as células do parênquima paliçádico cônicas comuns em espécies de ambientes úmidos (METCALFE; CHALK, 1983).

A anatomia das folhas é bastante variável, e sua estrutura pode refletir a disponibilidade de água e nutrientes. Contudo, Esau (1976) inferiu que, apesar de haver gradação variável em relação à constância de algumas características, a exemplo das características morfológicas das folhas, estas podem estar bem fixadas geneticamente em determinada espécie. Nesse sentido, é importante ressaltar que as diferenças observadas nas duas espécies estudadas se referem ao estádio de desenvolvimento inicial e podem não refletir necessariamente diferenças em outros estágios de desenvolvimento e nos indivíduos adultos.

Os resultados deste trabalho apontaram para alguns caracteres relacionados com os ambientes de ocorrência de O. arborea e O. fastigiata, bem como similaridades

Revista Árvore, Viçosa-MG, v.36, n.1, p.37-48, 2012 
em muitos aspectos morfológicos de suas sementes, plântulas e plantas jovens. Entretanto, a delimitação dessas espécies pode ser facilitada por meio da visualização de algumas características singulares identificadas neste estudo. A despeito das diferenças, há a possibilidade de lotes de sementes e, ou, mudas serem translocados entre as regiões Sudeste e CentroOeste. Ressalta-se a importância da utilização de sementes e mudas produzidas localmente nos programas de restauração e, ou, recuperação de áreas degradadas, com o intuito de evitar equívocos durante o plantio, introduzindo espécies em biomas distintos de sua distribuição original.

\section{AGRADECIMENTOS}

À Fundação de Apoio ao Desenvolvimento do Ensino, Ciência e Tecnologia do Estado de Mato Grosso do Sul (FUNDECT), pela concessão da bolsa de mestrado à primeira autora e pelo financiamento do seu projeto; e aos estagiários do Laboratório de Anatomia Vegetal/UFMS, pelo auxílio na preparação do material de estudo.

\section{REFERÊNCIAS}

BARBIERI, A. et al. Nodulação em leguminosas florestais em viveiros no sul de Minas Gerais. Cerne, v.4, n.1, p.145-153, 1998.

BARROSO, G. M. Sistemática de angiospermas do Brasil. Viçosa, MG: Universidade Federal de Viçosa, 1991. v.2. 377p.

BARRoso, G. M. et al. Frutos e sementes: morfologia aplicada à sistemática de dicotiledôneas. Viçosa, MG: Universidade Federal de Viçosa, 1999. 443p.

BUKASTSH, F. Benerkungen zur doppelfarbung astrablau-safranina. Microkosmos, v.61, p.255-260, 1972.

BURGER, H. Seedlings of some tropical trees and shrubs mainly of South East Asia. Wageningen: PUDOC, 1972. 399p.

CAMARGO, I. P.; CASTRO, E. M.; GAVILANES, M. L. Aspectos da anatomia e morfologia de amêndoas e plântulas de castanheira-do-brasil. Cerne, v.6, n.2, p.11-18, 2000.

Revista Árvore, Viçosa-MG, v.36, n.1, p.37-48, 2012
CARVALHO, A. P. F. et al. Variações sazonais nas concentrações de pigmentos e nutrientes em folhas de espécies de cerrado com diferentes estratégias fenológicas. Revista Brasileira de Botânica, v.30, n.1, p.19-27, 2007.

CAVALIN, P. Q.; MATTOS, E. A. Spatio-temporal variation of photosynthetic pigments in the CAM tree Clusia hilariana Schlechtendal associated with dry spells during the rainy season in southeastern Brazil. Trees, v. 21, p.671-675, 2007.

CHAVES, L. L. B.; CARNEIRO, J. G. A.; BARROSO, D. G. Crescimento de mudas de Anadenanthera macrocarpa (Benth) Brenan (angico-vermelho) em substrato fertilizado e inoculado com rizóbio. Revista Árvore, v.30, n.6, p. 911-919, 2006.

CRUZ, E. D.; MARTINS, F. O.; CARVALHO, J. E. U. Biometria de frutos de jatobá-curuba (Hymenaea intermedia Ducke, LeguminosaeCaesalpinoideae). Revista Brasileira de Botânica, v.24, n.2, p.161-165, 2001.

CUNHA, M. C. L.; FERREIRA, R. A. Aspectos morfológicos da semente e do desenvolvimento da planta jovem de Amburana cearensis (Arr. Cam.) A. C. Smith - cumaru - Leguminosae Papilionoideae. Revista Brasileira de Sementes, v.25, n.2, p.89-96, 2003.

DAVIDE, A. C.; FARIA, J. M. R.; BOTELHO, S. A. Propagação de espécies florestais. Belo Horizonte: CEMIG/ UFLA/ FAEPE, 1995. 40p.

DONADiO, N. M. M.; DEMATTÊ, M. E. S. P. Morfologia de frutos, sementes e plântulas de canafístula (Peltophorum dubium (Spreng.) Taub.) e jacarandá - da - Bahia (Dalbergia nigra (Vell.) Fr.All. ex Benth.) - Fabaceae. Revista Brasileira de Sementes, v.22, n.1, p.64-73, 2000.

ESAU, K. Anatomia das plantas com sementes. São Paulo: Edgard Blücher, 1976. 293 p.

ESAU, K. Anatomy of seed plants. 2.ed. New York: John Wiley \& Sons, 1977. 550p.

FAHN, A. Plant anatomy. 4.ed. Oxford: Pergamon Press, 1990. 588p. 
FENNER, B. M. Relationship between seed weight, ash content and seedling growth in twenty-four species of compositae. New Physiologist, v.95, p.697-706, 1983.

FERREIRA, R. A. et al. Caracterização morfológica de fruto, semente, plântula e muda de Dipteryx alata Vogel - baru (Leguminosae Papilionoideae). Cerne, v.4, n.1, p.73-87, 1998.

FERRI, M. G.; MENEZES, N. L.; MONTEIRO, W. R. Glossário ilustrado de botânica. São Paulo: Nobel, 1988. 198p.

GARNIER, E. et al. Consistency of species ranking based on functional leaf traits. New Phytologist, v.152, n.1, p. 69-83, 2001.

HUANTE, P.; RINCÓN, E.; ACOSTA, I. Nutrient availability and growth rate of 34 woody species from a tropical deciduous Forest in Mexico. Functional Ecology, v. 9, n. 6, p.849-858, 1995.

JENSEN, W. A. Botanical histochemistry principles and pratice. San Francisco: W. H. Freeman and Company, 1962. 408p.

JOHANSEN, D. A. Plant microtechnique. New York: McGraw Hill, 1940. 523p.

KRAUS, J. E.; ARDUIN, M. Manual básico de métodos em morfologia vegetal. Seropédica: Edur, 1997. 198p.

LLERAS, E. Differences in stomatal number per unit area within the some species under different microenvironmental conditions: a working hypothesis. Acta Amazonica, v. 7, n. 4, p.473-476, 1977.

LORENZI, H. Árvores brasileiras: manual de identificação e cultivo de plantas arbóreas nativas do Brasil. Nova Odessa: Instituto Plantarum, 1998. 368p.

METCALFE, C. R.; CHALK, L. Anatomy of the dicotyledons: leaves, stem, and wood in relation to taxonomy with notes on economic uses. Oxford: Clarendon Press, 1983. 297p.

MÍQUEL, S. Morphologie fonctionnele de plantules d'espèces forestières du Gabon. Bulletin du Muséum National d'Histoire Naturelle, v.9, n.1, p.101-121, 1987.
MOREIRA, F. M. S.; MOREIRA, F. W.

Características da germinação de sementes de 64 espécies de leguminosas florestais nativas da Amazônia, em condições de viveiro. Acta Amazônica, v.26, n.1/2, p.3-16, 1996.

OLIVEIRA, E. C. Morfologia de plântulas. In: AGUIAR, I. B.; PIÑA-RODRIGUES, F. C. M.; FIGLIOLIA, M. B. Sementes florestais tropicais. Brasília: ABRATES, 1993. p.175-213.

OLIVEIRA, D. M. T. Morfologia comparada de plântulas e plantas jovens de leguminosas em arbóreas nativas: espécies de Phaseoleae, Sophoreae, Swartzieae e Tephrosieae. Revista Brasileira de Botânica, v.24, n.1, p.85-97, 2001.

PINÃ-RODRIGUES, F. C. M. Guia prático para a colheita e manejo de sementes florestais tropicais. Rio de Janeiro: IDACO, 2002. 39p.

RESSEL, K. et al. Ecologia morfofuncional de plântulas de espécies arbóreas da Estação Ecológica do Panga, Uberlândia, Minas Gerais. Revista Brasileira de Botânica, v.27, n.2, p.311-323, 2004.

RODRIGUES, I. M. C.; GARCIA, F. C. P.

Papilionoideae (Leguminosae) arbóreas e lianas na estação de pesquisa, treinamento e educação ambiental (EPTEA), Mata do Paraíso, Viçosa, MG: Zona da Mata Mineira. Revista Árvore, v.31, n.3, p.521-532, 2007.

RODRIGUES, R. S.; TOZZI, A. M. G. A. Morfologia de plântulas de cinco leguminosas genistóides arbóreas do Brasil (LeguminosaePapilionoideae). Acta Botanica Brasilica, v.21, n.3, p.599-607, 2007.

RUDD, V. E. The american species of Ormosia (Leguminosae). National Herbarium, v.32, p.279-384, 1965.

SILVA, M. F. et al. Germinação natural de 10 leguminosas arbóreas da Amazônia. Acta Amazônica, v.18, n.1/2, p.9-26, 1988.

SIMS, D. A.; GAMON, J. A. Relationships between leaf pigment content and spectral reflectance across a wide range of species, leaf structures and developmental stages. Remote Sensing of Environment, v.81, n. 2/3, p.337-354, 2002.

SOUZA, L. A. Morfologia e anatomia vegetal: células, tecidos, órgãos e plântulas. Ponta Grossa: UEPG, 2003. 258p.

Revista Árvore, Viçosa-MG, v.36, n.1, p.37-48, 2012 
SOUZA, L. A. (Org). Sementes e plântulas: germinação, estrutura e adaptação. Ponta Grossa: Toda Palavra, 2009.

SPRENT, J. I. Nodulation in legumes. London: Royal Botanic Gardens, 2001. 146p.

VAN DER PIJL, L. Principles of seed dispersal in higher plants. 2.ed. Berlin: Springer-Verlag, 1982. 215p.

VIDAL, V. N.; VIDAL, M. R. R. Botânica Organografia. Viçosa, MG: Universidade Federal de Viçosa, 1995. 114 p.

VOGEL, E. F. Seedlings of dicotyledons: structure, development, types: descriptions of 150 woody Malesian taxa. Wageningen: Centre for Publishing and Documentation, 1980. 445p.
ZAR, J. H. Biostatistical analysis. 3.ed. New Jersey: Prentice Hall, 1996. 718p.

WATSON, R. W. The effect of cuticular hardening on the form of epidermal cells. New

Phytology, v.41, n.4, p.223-229, 1942.

WERKER, E. Trichome diversity and development. In: HALLAHAN, D. L.; GRAY, J. C. (Eds.) Plant Trichomes. London: Academic Press, 2000. p.1-30. (Advances in Botanical Research, 31)

WILKINSON, H. P. The plant surface. In: METCALFE, C. R.; CHALK, L. (Eds.) Anatomy of the Dicotyledons Systematic Anatomy of the leaf and stem. Oxford: Clarendon Press, 1979. p.97-165. 